to de royalty, houvesse rateio de despesas, com pesquisas realizadas aqui e no exterior, e acesso recíproco a umas e outras, de pesquisadores estrangeiros e brasileiros.

O problema nesse campo está ligado à questão da legislação sobre capital estrangeiro. Não creio que se consiga obter transferência de tecnologia de ponta no quadro atual, em que existe praticamente liberdade total de investimento em qualquer setor, com pouquíssimas exceções. Basta que uma empresa estrangeira não pleiteie incentivos para que ela possa se instalar no Brasil, com vistas a uma presença no mercado brasileiro atual e futuro. Acuidade não falta à empresa estrangeira para saber que esse mercado representa um potencial enorme. Cabe a nós, através de legislação que permita seletividade do investimento externo, estabelecer condições que assegurem vantagens recíprocas, entre as quais se destacaria, para o lado brasileiro, a exigência de realização de pesquisa no Brasil e do recebimento de tecnologia aberta, e, do lado do investidor, a participação do mercado e a segurança da estabilidade das regras estabelecidas. O ideal seria um entendimento que proporcionasse aos nossos técnicos o acesso à pesquisa realizada no exterior e, também, na realização de pesquisa no Brasil por parte das empresas estrangeiras, a participação de técnicos brasileiros. Porque, na realidade, a empresa estrangeira praticamente não faz pesquisa no Brasil, e para aquien- via pacotes fechados, o que, no estágio atual de nosso desenvolvimento, não parece razoável. Adotado que fosse um esquema de cooperação, teríamos a vantagem de um conhecimento mais amplo e da formação de recursos humanos altamente qualificados, permitindo-nos absorver tecnologia cada vez mais sofisticada. Do lado do investidor poderia parecer uma desvantagem partilhar essa tecnologia, mas, na realidade, não vejo o assunto sob esse prisma. A empresa estrangeira, além de ter nossa participação num rateio de despesas de pesquisa, estimularia a criatividade do lado brasileiro, o que amanhã lhe permitiria auferir vantagens de know-how desenvolvido no Brasil.

A atual conjuntura brasileira não é favorável a alterações na legislação sobre o investimento externo, mas nem por isso o problema e suas possíveis soluções deve deixar de ser colocado, tanto mais que as medidas que sugiro não representam, em absoluto, qualquer tipo de antagonismo à empresa estrangeira. Fala-se muito em aprofundar e acelerar o chamado diálogo norte-sul entre os países industrializados e em desenvolvimento, e isso, parece, é um imperativo para a solução dos graves problemas socias que nos afetam. Ora, a aproximação no campo tecnológico é, sem dúvida alguma, um dos fatores mais importantes da efetividade desse diálogo, e nela reside uma grande esperança, que não deveria ser frustrada.

\title{
Transferência de tecnologia e exportação
}

Arthur Carlos Bandeira, presidente do Instituto Nacional da Propriedade Industrial - INPI, do Ministério da Indústria e Comércio - MIC.
Arthur Carlos Bandeira

apresentar-se-ão alguns problemas e sugestões para o campo da exportação.

A exportação de tecnologia pode induzir à exportação de insumos, componentes, máquinas e equipamentos. Há, porém, que se atentar para o fato de que o país receptor da tecnologia somente realizará a transação se o saldo de divisas Ihe for favorável. Expliquemos: os pagamentos ao exterior por determinada tecnologia, bem como pelas necessidades de se importarem máquinas e equipamentos deverão sempre ser inferiores aos gastōs das importações que foram substituídas. De certa maneira, o fornecedor de tecnologia terá o seu lucro diminuí- 
do e até mesmo poderá estar definitivamente perdendo o mercado. Logicamente, o fornecedor da tecnologia só efetuará este tipo de negociação se a isto estiver obrigado por, digamos, impossibilidade da parte do país receptor em pagar as suas importações de mercadorias.

Tal constatação é uma explicação clara das imperfeições e abusos usualmente encontrados no comércio da tecnologia, principalmente nos contratos que se destinam à produção de mercadorias e que são os de propriedade industrial, marcas e patentes e os de trading secrets elou know-how. Os contratos de serviços técnicos, como os de engenharia, montagem e supervisão, já escapam à problemática comentada e hoje representam a quase totalidade de exportações de tecnologia.

Vale ainda advertir que, embora juridicamente os contratos de serviços sejam considerados de transferência de tecnologia, em verdade, isto não ocorre, porque se limitam a prestar o serviço sem nada transferir de tecnologia em alguns casos.

Algumas características apontam para a possibilidade de a nossa indústria iniciar um processo de geração de tecnologia própiria e, posteriormente, já em etapa mais avançada, começar a exportar a tecnologia. Classifiquemos as empresas em dois grupos: exportadores de mercadorias e exportadores de tecnologia. Separadamente, busquemos analisar como o comércio de tecnologia pode influir na atuação destas empresas, exportadoras de mercadorias. A existência desses contratos de transferência de tecnologia pode ser fator limitativo ao mercado exportador.

Em primeiro lugar, o contrato pode conter restrição total ou parcial à exportação. Felizmente, no caso brasileiro, desde o início do INPI, tem se negado averbação para qualquer forma restritiva de exportação. Há alguns anos, tal procedimento do INPI, baseado nos artigos do atual Código da Propriedade Industrial, foi bastante criticado e combatido. Hoje o empresariado nacional já tem uma consciência clara de que esta é uma restrição abusiva do poder econômico e, como tal, inaceitável. Todavia, se o licenciamento da tecnologia não impedir a exportação, poderá, eventualmente, impedir a importação. Alegislação nacional de patentes em quase todos os países concede ao titular do privilégio o direito de importação. Além disso, o Convênio da União de Paris considera uso da patente a importação do produto protegido pelo privilégio. Em ambas as situações poder-se-á realizar a importação desde que se constate abuso econômico do titular da patente. Mas é compreensível a vantagem do titular, aliado às dificuldades do importador, em provar estas táticas abusivas. Dependendo do produto e do país importador, o titular do privilégio, em muitos casos, prefere não alegar direito de importação. Portanto, importar tecnologia como uma forma salutar de acelerar o desenvolvimento e formar o mercado nacional pode conduzir a entraves quando surgir a possibilidade de iniciar a etapa de exportação.

Certamente, os ofertantes de tecnologia não pretendem criar, com esta transação, nova concorrente no mercado externo. No caso brasileiro tal problema não deverá tardar, à medida que se começa a obter maior participação em novos mercados para os nossos produtos industrializados. Nesta oportunidade a empresa exportadora de mercadorias verse-á compelida a substituir a importação de tecnologia, ou seja, criar seus próprios produtos e processos, pois os usuários ofertantes de tecnologia evitarão manter o atual padrão de trasferência de tecnologia.

O outro problema que ele considera mais sério são as marcas. A participação no comércio exterior através da exportação de produtos, principalmente no caso de bens de consumo, somente é possível pelo uso de marca própria. O Japão é muito citado quando se fala em tecnologia por ser um país que copiou, ao invés de negociar a transferência de tecnologia. Na verdade o sucesso japonês pode meIhor ser explicado pela inexistência de marcas estrangeiras. Há cerca de vinte anos, é bom recordar, não se consideravam as marcas japonesas em produtos elétricos ou eletrodomésticos, em máquinas fotográficas ou relógios, ou automóveis. Hoje, são as marcas mais conhecidas e através delas as empresas japonesas têm certo controle do mercado internacional. Em nosso país, infelizmente, ocorreu e ocorre o uso indiscriminado de marcas estrangeiras. A legislação nacional, seja de inversões estrangeiras, imposto sobre a renda ou propriedade industrial, adota várias formas de desincentivos ao uso de marcas estrangeiras. Como é facilmente perceptível, esses desincentivos não se têm mostrado suficientes para reduzir perspectiva de lucro de curto prazo nem de eliminar o risco de desnacionalização da empresa. Se o uso indiscriminado de marcas estrangeiras no mercado local pode gerar problemas, o fenômeno se agrava quando analisado em termos de exportação. Os canais de exportação no princípio são de mais fácil entrada; todavia, os fluxos são sempre de controle do titular da marca. Assim, poderá ocorrer o cancelamento de mercado, a diminuição de volume exportado, enfim uma série de fatores contrários aos interesses da empresa exportadora.

Em suma, a empresa nacional que possui contrato de transferência de tecnologia deve estar alertada para os prós e os contras. Por outro lado, à medida em que se torna crescentemente imprescindível para o país o aumento de suas exportações industriais, o governo irá sendo obrigado a tomar me- 
didas de incentivo e desincentivos a determinadas transações tecnológicas, às exportadoras de tecnologia. Estas empresas tornam-se exportadoras de tecnologia à medida em que percebem a impossibilidade de se manterem como exportadora de produtos ou que encontra-se neste canal a primeira e única forma de penetrar num outro mercado. A exportação de tecnologia, conforme já vimos, encerra um processo indutivo de exportação de insumos, componentes, máquinas e equipamentos e serviços técnicos. Infelizmente não se pode pretender que qualquer empresa se transforme rapidamente em exportadora tecnológica. A empresa exportadora de tecnologia, além de possuir pleno controle sobre o seu processo produtivo, deve ter conhecimentos organizados de tal maneira que permitam a sua pronta utilização por outras empresas. Pressupõe um porte industrial avançado, seja econômico ou administrativo.

Por essa razão, no caso brasileiro, seriam poucas as empresas que poderiam se capacitar para tal tipo de transação a curto prazo.

Outro aspecto é que tal empresa deve estar próxima de gerar a sua própria tecnologia ou, meIhor ainda, já possuir autonomia tecnológica. É possível imaginar-se exportar tecnologia anteriormente importada, mas tal ocorrência será mais ou menos viável se a empresa foi capaz de criar alguns aperfeiçoamentos técnicos significativos. Neste último caso, a antiga licenciante pode, inclusive, solicitar que sua licenciada participe da exportação de tecnologia ou vice-versa. Este tipo de negociação pode ocorrer por diversas razões, desde o fato puramente tecnológico até os de base cultural e o de linguagem.

Uma sugestão seria com relação às empresas exportadoras de tecnologias: após a definição do perfil industrial de algumas empresas, e, concluindose pela existência de um potencial de exportação de tecnologia, haveria que se estabelecer um programa de administração dos conhecimentos tecnoló- gicos. Indiretamente, o INPI, já vem dando alguns passos prévios neste sentido; alguns cursos de propriedade industrial para os técnicos de empresas nacionais começam a ser ministrados, como uma forma de motivar a criação de núcleos de patentes e marcas em nossas empresas industriais, assim como, é comum entre empresas norte-americanas, européias e japonesas. Além disso, juntamente com a Escola Interamericana de Administração Pública, temos programado para os próximos três anos cursos para negociadores de tecnologia, os quais, embora voltados para os problemas do importador também podem vir a ser úteis para o caso de exportação. Ainda para este tipo de empresa, quando detectado o seu potencial exportador, deveriam os órgãos de financiamento proporcionar algum tipo de preferência em projetos de desenvolvimento tecnológico.

Do exposto, é lícito concluir que os problemas de exportação de tecnologia são de complexidade bem maior do que as exportações tradicionais, implicando em comércio de outros fatores, a saber: pesquisa e desenvolvimento; alta capacitação de pessoal, tanto em termos quantitativos como qualitativos; e formas de incentivos dentro de uma ótica de longo prazo. Neste caso já se tem programas de governo para formação de pessoal a nível de CNPq, Finep e também de projetos de pesquisas além da área de pessoal, que é o programa do Fundo de Amparo à Tecnologia - Funat, implementado pela Secretaria de Tecnologia Industrial, do MIC.

Em conclusão, é mister esclarecer que a independência tecnológica não é traduzida pela capacidade de exportar ou importar tecnologia, visto que todos os países desenvolvidos, com exceção dos Estados Unidos da América do Norte e ocasionalmente o Japão, são importadores desse insumo; a independência tecnológica deve ser entendida como a capacidade de uma nação selecionar adequadamente as tecnologias a serem adquiridas elou desenvolvidas, objetivando o máximo de efeito econômicosocial.

\section{Desenvolvimento de tecnologia e penetração no mercado}

John F. Dealy, advogado, ex-presidente da Fairchild Industry.

John F. Dealy

Gostaria de acrescentar o meu endosso à tese de que a cultura geral que geramos, 